\author{
Анатолій КАРАСЕВИЧ \\ orcid.org / 0000-0002-4261-6386 \\ кандидат філософських наук, \\ професор кафедри суспільних дисииплін \\ Уманського державного педагогічного \\ університету імені Павла Тичини \\ (Україна. Умань) \\ karasevych@ukr.net \\ Марина ФЕДОРОВА \\ мazicmp icmopii \\ Уманського державного педагогічного \\ університету імені Павла Тичини \\ (Украӥна. Умань) \\ deliversinspiration03@gmail.com
}

\title{
НОРМАТИВНО-ПРАВОВА БАЗА УКРАЇНСЬКОГО КІНЕМАТОГРАФА: ПОРІВНЯЛЬНИЙ АНАЛІЗ РАДЯНСЬКОГО І ПОСТРАДЯНСЬКОГО ПЕРІОДІВ
}

\begin{abstract}
Становлення украӥнського кіно на правовому рівні мало ряд закономірностей, етапів $і$ відповідало основним рисам загальновідомих періодів історії перебування України у складі СРСР та незалежної України.

В радянській історіографії першим нормативно-правовим актом, щчо стосувався кінематографа, вважається постанова Тимчасового Робітничо-Селянського Уряду УСРР від 8 січня 1919 р., відповідно до якої усі театри та кінотеатри передавалися у підпорядкування відділу освіти. 27 серпня 1919 р. голова Раднаркому РСФРР В. Ленін підписав декрет «Про перехід фотографічної і кінематографічної торгівлі $і$ промисловості у відання Народного комісаріату освіти». Дата підписання цьього документу стала вважатися днем народження всього радянського кіно, украӥнського у тому числі.

В лютому 1922 р. відбулась реорганізачія утвореного раніме Всеукрайнського кінокомітету у Всеукраїнське фото-кіно управління (ВУФКУ). A вже 18 червня 1922 p. «для управління фото- $i$ кінопромисловістю УРСР, ї̈ організачії, експлуатаиії ї̈ виробництва, а також для організації усіх додаткових виробництв» Наркомосвіти УРСР затверджує «Положення про Фото-кіноуправління». 3 тих часів ия організація зазнавала постійних змін та реформувань. А отже згодом питаннями кіно будуть завідувати Управління в справах Кінематографії, Міністерство Кінематографії Української РСР, Головне управління з виробництва фільмів, Державний комітет по кінематографії УРСР. 3 прийняттям незалежності Державний фонд украӥнської кінематографії, Державна служба кінематографії $i$ нарешті Державне агентство Украӥни з питань кіно.

Діяльність всіх иих установ контролювалась та формувалась відповідними законодавчими актами та документами, компаративний аналіз яких і має місие у даній статті.
\end{abstract}

Ключові слова: кінематограф, радянське кіно, украӥнський начіональний кінематограф, фільм, нормативно-правові джерела. 


\section{REGULATORY AND LEGAL BASIS OF UKRAINIAN CINEMATOGRAPHY: COMPARATIVE ANALYSIS OF THE SOVIET AND POST-SOVIET PERIODS}

Creative biography of Ukrainian cinema is a constant spiritual search, artistic discoveries, struggle for the right to exist and create freely. However, in Ukraine, with the understanding of the past of its own cinema, things do not look the best, due to the large amount of material involved not in the cultural but in the political context of history. The relevance of the article is due to the lack of a comprehensive study of the analysis of legal sources in the field of Soviet and post-Soviet cinema.

The formation of Ukrainian cinema at the legal level had a number of patterns, stages and corresponded to the main features of well-known periods in the history of Ukraine's membership in the USSR and independent Ukraine.

In Soviet historiography, the first legal act concerning cinema was the resolution of the Provisional Workers 'and Peasants' Government of the USSR on January 8, 1919, according to which all theaters and cinemas were transferred to the Department of Education. On August 27, 1919, the chairman of the People's Commissar of the SSFSR, V. Lenin, signed a decree "On the Transfer of the Photographic and Cinematographic Trade and Industry to the People's Commissariat of Education.» The date of signing this document was considered the birthday of all Soviet cinema, including Ukrainian.

In February 1922, the previously formed All-Ukrainian Film Committee was reorganized into the All-Ukrainian Photo-Film Department (AUPFD). And already on June 18, 1922, "for the management of the photo and film industry of the USSR, its organization, operation of its production, as well as for the organization of all additional productions, » the People's Commissariat of Education of the USSR approved the "Regulations on Photo and Film Management.» Since then, this organization has undergone constant changes and reforms.

In general, from the appearance of cinema to its demonstration on our screens today, many leading government agencies have been created, the purpose of which was to subordinate the film industry as an important factor influencing the minds of people. In the Soviet period, these were the All-Ukrainian Photo Cinema Department, the Cinematography Department, the Ministry of Cinematography of the Ukrainian SSR, the Main Directorate for Film Production, and the State Cinematography Committee of the Ukrainian SSR. When Ukraine became independent - the State Fund of Ukrainian Cinematography, the State Cinematography Service and finally the State Agency of Ukraine for Cinema.

The general analysis of normative-legal documents accepted for the management of these establishments leads to several conclusions. During the Soviet period, the main tasks of the state in the field of cinema, which were reflected in legal documents, were of course the filming of the territory of Ukraine, the formation of material and technical base of cinema and the spread of Soviet propaganda through ideological and feature films. Cinematography was recognized as one of the most important means of agitation. The period of independent Ukraine and the formation of independent national cinema began with the Law of Ukraine «On Cinema» in 1998. Gone are the days and cinema is no longer subject to ideological principles enshrined at the state level. Ukrainian cinema was able to stand on its own two feet. To popularize not the party, but the nation, which is now the priority of state policy in the field of cinema, as evidenced in particular by recent legislative changes from President V. Zelenskyi.

Key words: cinematography, Soviet cinema, Ukrainian national cinematography, film, legal sources.

Постановка проблеми. Український кінематограф має вагомі здобутки, що збагатили світову культуру оригінальними творами, які відображають величну історію нашого народу, його самобутність та духовну красу. Творча біографія українського кіно - це постійний духовний пошук, художні відкриття, боротьба за право існувати та вільно творити. Проте в Україні 3 осмисленням минувшини власного кінематографа справи виглядають не найкращим чином, що пов’язано 3 великою кількістю матеріалу, заангажованого не культурним, а політичним контекстом історії. Актуальність статті спричинена відсутністю комплексного дослідження присвяченого аналізу 
нормативно-правових документів в галузі радянського та пострадянського кінематографа.

Аналіз досліджень. Історіографія творення кінематографу на теренах України представлена працями як радянських дослідників, так i працями сучасних українських істориків.

Зокрема, варто відзначити монографії українського кінознавця Володимира Миславського (Миславський, 2018), в яких було вперше, на основі розгляду широкого спектру маловідомих публікацій в російській та українській періодичній пресі та архівних матеріалів, реконструйовано становлення i функціонування кінофікації і кінопрокату на початку XX століття. А також модель структури і організації управління українським кінематографом у 1920тi pp.

Працю «Іторія українського кіно. Т. 2.: 1930 - 1945» у редакції Григорія Скрипника (Скрипник, 2016) присвячено розвитку екранного мистецтва в Україні впродовж 1930-1945 років. Вона висвітлює як власне мистецький процес, так і сфери освіти, кінопреси, кінопрокату і кінофікації, а також тогочасної державної політики щодо кінокультури.

Цінний джерельний, в тому числі i фактичний матеріал присвячений історії кінематографа знаходимо у працях українського кінокритика i кіносценариста Сергія Тримбача (Тримбач, 2016). Матеріали охоплюють період від становлення українського кіно на межі XIX - XX ст. до сучасної доби, коли відбулось справжнє відродження і оновлення кінематографа України.

Мета статті. Дослідження історії українського кінематографа від його зародження в радянську добу і до його подальшого розвитку в добу сучасної незалежної України, через призму нормативно-правових документів та законодавчих актів.

Виклад основного матеріалу. Становлення кіно на правовому рівні мало ряд закономірностей, етапів і відповідало основним рисам загальновідомих періодів історії перебування України у складі СРСР та незалежної України. Опрацювання обсягу згаданих у статті документів вимагає виключного 
застосування медіаграмотності кожного хто 3 ними ознайомиться (Тримбач, 2016: 15$)$.

В 1919 р. український кінематограф, як і все того часу, перейшов у розряд радянського. В цілому, з 1919 р. до початку 1922 р. кіногалузь в Україні зазнала три організаційні стадії свого розвитку. Перша стадія - передача кінотеатрів і складів в окремих містах у відання губернських відділів народної освіти Наркомосвіти УРСР і губернських відділів політико-просвітницького комітету Наркомосвіти УРСР, а також повітових відділів народної освіти Наркомосвіти УРСР і повітових відділів політико-просвітницького комітету Наркомосвіти УРСР. Цей період характеризується відсутністю державних завдань в області кінематографії і різнобоєм в роботі кіно (Миславський, 2018: 312).

В радянській історіографії першим нормативно-правовим актом, що стосувався кінематографа, вважається постанова Тимчасового РобітничоСелянського Уряду УСРР від 8 січня 1919 р., відповідно до якої усі театри та кінотеатри передавалися у підпорядкування відділу освіти. На останній покладено обов'язок «розробити інструкцію місцевим радам про порядок завідування театрами і кінематографами» (Росляк, 2014 (а): 171-172).

Друга стадія знаменується створенням 9 січня 1919 р. при Відділі мистецтв Наркомосвіти УРСР Кінематографічного комітету. Було створено апарат управління державним сектором кінематографії у складі Наркомосвіти і мережі безпосередньо підпорядкованих йому місцевих органів - окружних фотокінокомітетів і кіносекцій у складі губернських виконавчих комітетів. 18 січня на посаду голови Кінокомітету Наркомосвіти призначено режисера О. Аркатова (Миславський, 2018: 313).

Найбільш відомим документом 3 націоналізації кінотеатрів $є$ декрет Раднаркому УСРР від 25 лютого 1919 р. про електротеатри. Складався він 3 двох частин. У першій частині, йшлося про націоналізацію аж трьох харківський кінотеатрів: «Ампіру», «Модерну» та «Мішеля». Їх проголосили власністю УСРР та передали до відома Всеукраїнського кінокомітету, незадовго перед тим створеного. Націоналізовані електротеатри отримали нові 
революційні назви: відповідно імені Карла Лібкнехта, Рози Люксембург та III Інтернаціоналу.

Друга частина проголошувала про те, що всі кінематографічні картини наукового i культурно-виховного характеру оголошуються власністю Української Соціалістичної Радянської Республіки і передаються до відання Кінокомітету Комісаріату народної освіти. На виконання цього декрету 2 березня Всеукраїнський кінокомітет видав власну постанову в Харкові та 12 липня - у Києві.

Кінокомітет також намагався відстоювати свої сфери впливу. Постановою від 1 квітня 1919 р. оголошено, що всі приміщення кіно- та фотоустанов «знаходяться у винятковому віданні Всеукраїнського кінокомітету, перебувають у нього на обліку і не можуть бути реквізовані та ущільнені без відома та згоди Всеукраїнського кінокомітету» (Росляк, 2011 (c): 171-175).

Триваюча Громадянська війна, що супроводжувалася надзвичайними заходами радянського уряду, потребувала створення інформаційної підтримки правлячого режиму. Кінематографія була визнана одним із найважливіших засобів агітації. Ідея розвивати кіно в цілях посилення впливу пролетаріату на інші класи суспільства пролунала вже у березні 1919 р. на VIII з’їзді РКП(б). Організація широкомасштабної кінопропаганди вимагала створення відповідного апарату, забезпечення матеріальної і фінансової основи цієї діяльності. Важливим супутнім завданням було встановлення контролю над приватними кіноорганізаціями в цілях запобігання контрагітації i контрпропаганди, забезпечення їхнього сприяння завданням держави. Серед найбільш суттєвих чинників, що унеможливлювали розвиток системи прокату Кінокомітету, можна вважати сильну інфляцію 3 повною відміною грошового обігу перед НЕПом, Громадянську війну, що супроводжувалася господарською розрухою, складністю транспортних сполучень тощо (Миславський, 2018: 314).

У тому ж таки 1919 р. 3 метою розмежування компетенції різних державний відомств по відношенню до приміщень культури i мистецтва Раднарком УСРР видав декрет «Про передачу історичних і художніх цінностей 
до відання Народного комісаріату освіти». В частині присвяченій «десятій музі», кінематографічні ательє, кінотеатри, кіноконтори передавалися до освітнього відомства і звільнялися від «реквізицій і зайняття іншими відомствами, установами, організаціями та особами». Використовувати їх можна було лише 3 дозволу Наркомосу. Ще один пункт декрету поширював такі ж повноваження освітнього відомства на кінотехніку, кінофільми. Вочевидь цей декрет не особливо виконувався. Тому Раднарком вкотре змушений був звертатися до згаданої проблеми. Черговий декрет «Про приміщення театрів і кінематографів» визначав, що «приміщення, в яких перебувають театри, кінематографи не можуть бути зайняті за розпорядженням житлово-земського відділу без попереднього узгодження 3 Народним комісаріатом освіти або місцевим органом народної освіти».

27 серпня 1919 р. голова Раднаркому РСФРР В. Ленін підписав декрет «Про перехід фотографічної і кінематографічної торгівлі і промисловості у відання Народного комісаріату освіти». Дата підписання цього документу стала вважатися днем народження всього радянського кіно, українського у тому числі, і не піддавалася радянською владою жодним сумнівам (Росляк, 2011 (c): 173-175).

У декреті йшлося про передачу всієї фото- і кіноторгівлі та промисловості на території РСФРР до відання освітнього відомства. На виконання даного рішення Наркоматові освіти РСФРР надавались певні права: націоналізації фотокінопідприємств або ж усієї фотокінопромисловості; реквізиції підприємств, фотокінотоварів, матеріалів, інструментів; установлення твердих і граничних цін на фотокіносировину; здійснення обліку й контролю фотокіноторгівлі і промисловості; регулювання фотокіноторгівлі та промисловості шляхом видання відповідних постанов (Гак, 1973: 51). Саме так почався процес націоналізації кіноматографа радянською владою.

Історія вітчизняного кіно, написана радянськими кінознавцями, невпинно рекомендувала декрет від 27 серпня 1919 р. як основоположний документ, що 
визначив головні напрямки соціалістичного будівництва в області екрану (Евтушенко, 2013: 130-133).

3 третім приходом радянської влади розпочинається чергова націоналізація кінопідприємств. Наказом губревкому з метою «включення кінематографії в загальний план справи народної освіти і пристосування цієї галузі в знаряддя освіти та пропаганди ідей радянського будівництва і соціалістичної культури» 3 20 березня 1920 р. були оголошені націоналізованими разом з усім майном усі кінопрокатні контори, кінотеатри, кінолабораторії, кіноательє, кіномеханічні майстерні, склади кіносировини та майна в м. Києві та губернії. Все майно згаданих установ поступово надходило в розпорядження кіносекції позашкільного підвідділу губернського відділу народної освіти. На виконання вимог Наркомосу низку розпоряджень видають органи місцевої влади. Так 4 липня 1920 р. опубліковано наказ Київського губернського відділу народної освіти, який, окрім вже традиційних вимог зареєструвати кінопідприємства, заборонити вивозити кіноапаратуру, фільми та ввести цензурні обмеження, містив пункт про націоналізацію аж одного кінотеатра: «3 8 липня 1920 р. кінотеатр колишнього Шанцера з усім його інвентарем оголошується власністю УСРР і з усім складом службовців переходить до відома губвідділу наросвіти».

В цей період подібні акції відбувалися і в інших містах. В Одесі наказом губернського відділу народної освіти були націоналізовані кінопрокатні контори Дмитра Харитонова, братів Шарля та Фернана Пате, Костянтина Борисова та інших. Їх майно оголошено власністю держави (Росляк, 2014 (c): 173-175).

А 21 січня 1920 р. у 4 випуску журналу «Кіно-тиждень» з’явився коментар Володимира Леніна, про найважливіше з усіх мистецтв. Йдеться про те, що всі стрічки, які демонструються в РСФРС, мають бути зареєстровані i пронумеровані в Наркомосі. Для кожної програми кіновистави повинна бути встановлена певна пропорція:

а) розважальні картини, спеціально для реклами і доходу (звичайно без похабщини і контрреволюції); 
б) під фірмою «3 життя народів усіх країн» - картини спеціального пропагандистського змісту, такі як: колоніальна політика Англії та Індії, робота Ліги Націй, голодуючі Берліна і т. п.

Зазначалося, що потрібно показувати не тільки кіно, а й цікаві для пропаганди фотографії з відповідними написами. Картини пропагандистського i виховного характеру потрібно давати на перевірку старим марксистам i літераторам. Спеціально звернути увагу на організацію кінотеатрів у селах та на Сході, де вони є новинками і тому радянська пропаганда буде там особливо успішною (Гак, 1973: с. 42).

Третя стадія - реорганізація Всеукраїнського кінокомітету у Всеукраїнське фото-кіно управління (ВУФКУ) в лютому 1922 р. Із закінченням Громадянської війни завершувалося проведення агітаційних кампаній - рейсів потягів, інших акцій, що складали основу функціонування Кінокомітету на початковому етапі його існування. Кінокомітет постав перед необхідністю перегляду своєї діяльності. У кінці 1920 р. - середині 1921 р. спостерігається посилення його інтересу до господарської сторони функціонування державного сектора кінематографії, наявні спроби організувати його роботу відповідно до принципу самоокупності.

Рішення про перетворення Всеукраїнського кінокомітету й переведення його на рейки госпрозрахунку було прийняте в першій декаді лютого 1922 рр. Про це свідчать опубліковані резолюції Політосвітсекції Всеукраїнської наради по політосвітроботі губагітпропів і губполітосвіти, що проходила в Харкові 32 по 8 лютого 1922 р. По Худсектору Політосвіти було прийнято вісім резолюцій, у тому числі три - про перетворення Кінокомітету. На нараді розглядався проект перетворення Всеукраїнського кінокомітету на трест, який мав здійснювати свою діяльність на основі госпрозрахунку. У кінці лютого Всеукраїнський фотокінокомітет перейменовано у Всеукраїнське фотокіноуправління під головуванням колишнього директора Кінокомітету В. В. Прокоф'єва і на початку березня переведено з Києва до Харкова. 
У березні-квітні 1922 р., у сформованому госпрозрахунковому тресті ВУФКУ обирається правління, призначається дирекція губернських і районних відділень. Але окрім фінансово-господарського перетворення необхідно було об'єднати і усю кіносправу України і сконцентрувати керівництво ним в єдиному центрі. ВУФКУ підпорядковувалось не Наркомосвіти, а безпосередньо одному із його підрозділів - Головполітосвіти. 3 метою концентрації кіносправи 11 квітня 1922 р. видається наказ № 57 по Головному політикоосвітньому комітету за підписом голови Головполітосвіти Г. Дубко. У наказі було встановлено, що після формування ВУФКУ йому надається монопольне право завідування і управління усіма галузями фото- і кіновиробництва, експлуатації усіх кінотеатрів, що знаходилися не території України, а також підсобних підприємств, що обслуговують фото- і кінопромисловість.

А вже 18 червня 1922 р. «для управління фото- і кінопромисловістю УРСР, iii організації, експлуатації іï виробництва, а також для організації усіх додаткових виробництв» Наркомосвіти УРСР затверджує «Положення про Фото-кіноуправління». Положення підписали Народний Комісар Освіти Г. Гринько і заступник Голови Головполітосвіти Г. Дубко (Миславський, 2018: 320-326).

Санкціонована в квітні 1923 р. XII з’їздом РКП(б) (який рекомендував формувати державні органи національних республік переважно з представників місцевого населення, які знають мову, звичаї, вдачу відповідних народів; видати спеціальні закони, що забезпечували б вживання рідної мови в усіх державних установах), політика коренізації в радянських республіках отримала відповідні назви за географічним принципом: в УСРР - українізації, в Білоруській СРР - білорусизації тощо.

На виконання рішення партійних органів Раднарком УСРР 27 липня 1923 p. видав декрет «Про заходи в справі українізації шкільно-виховних i культурно-освітніх установ», в якому передбачалося «завершити ухвалені радянською владою заходи» щодо забезпечення українському народові виховання й навчання його рідною мовою, а також найширший розвиток 
національно-культурних форм його життя - мови, літератури й мистецтва, як могутніх чинників залучення широких верств населення до світової культури.

У тому ж році українізація розпочалася і в кінематографі, хоча на перших порах здійснювалася дуже повільно. Планувалося виготовляти титри українською мовою для закордонних фільмів із сільського господарства, деяких наукових, частини агітаційних і науково-виробничих картин. Чи не найлегшим завданням 3 українізації стало титрування фільмів українською мовою. Паралельно з титруванням фільмів відбувався перехід на рекламу українською мовою (Росляк, 2014 (b): 215).

У січні 1929 р. ЦК ВКП(б) ухвалив постанову «про керівні кадри працівників кінематографії». Було прийнято рішення на форсоване залучення талановитої молоді 3 селянського та робітничого середовища в режисуру i сценарні майстерні, які будуть говорити 3 народом на одній мові (Раззаков, 2008 : 23). На виконання цієї постанови 13 лютого 1930 р. Раднарком СРСР видає свою постанову «Про утворення загальносоюзного об'єднання по кінофотопромисловості» у віданні ВРНГ СРСР. У сформованому об'єднанні, що згодом було назване Совкіно, зосереджувалась уся справа по виробництву кіно, фотоапаратури (знімальної проекційної, освітлювальної та ін.), фотокіноустаткування і матеріалів (плівок, пластинок, паперу, фотохімікалій і т. п.), а також усе діловодство кінокартин, їх прокату і експлуатації.

Згідно з постановою РНК СРСР від 9 березня 1930 р. усі справи ліквідованого Кінокомітету СРСР передавалися до Совкіно. Всесоюзне об’єднання кінофотопромисловості мало правління, очолюване головою, секретаріат, управління справами i 9 секторів. Була створена і спеціальна комісія для координації методів роботи кінопрокату і управління кіномережею на периферії (Миславський, 2018: 373-374).

11 травня 1930 р. Рада праці й оборони СРСР ухвалила постанову «Основні положення статуту Загальносоюзного об’єднання кінофотопромисловості», що проголошувала створення у складі загальносоюзного об’єднання кінотрестів, які прийшли на зміну 
республіканським кіноорганізаціям. Принциповим був факт: кінотрести були позбавлені функцій виробництва фільмів, права здійснення імпортноекспортних операцій. Їхню діяльність обмежили організацією кіномережі, прокатом фільмів, експлуатацією кіноустановок. Усі кінофабрики (за винятком Київської й Одеської) були підпорядковані безпосередньо загальносоюзному центру.

На початку червня голова Правління «Союзкіно» М. Рютін у листі до керівника української кінематографії І. Воробйова вже вимагав віддати наказ про припинення самостійного функціонування ВУФКУ та проведення низки заходів щодо його підпорядкування (Росляк, 2014 (a): 112-126).

Отож, у 1930 р. ВУФКУ було реорганізовано в державний український трест кінофотопромисловості «Українфільм». Водночас розпочалася робота 3 розробки статуту нової української кіноорганізації. Попереднє затвердження статуту тресту «Українфільм» відбувалося на засіданні Правління «Союзкіно» 28 червня 1930 р. Однак тільки 9 листопада того самого року статут Державного українського тресту кінопромисловості «Українфільм» (таку назву отримав наступник ВУФКУ) було затверджено на засіданні Президії ВРНГ СРСР (Скрипник, 2016: 8).

Жодних надій на автономію документ не залишав. У статуті чітко прописали положення про те, що трест «Українфільм» перебуває у віданні ВРНГ СРСР і входить до складу кінофотооб'єднання «Союзкіно». Останнє, відповідно і призначало керівництво «Українфільму» (Росляк, 2014 (а): 112126).

У постанові ЦК ВКП (б) «Про радянську кінематографію» від 8 грудня 1931 р. зазначалося: «Завдання радянського кіно полягає в створенні фільмів такої якості, щоб забезпечити прагнення робітників і колгоспників отримати від кіно розваги, відпочинок, підняття свого культурного і політичного рівня як будівників соціалізму. Відповідно до цього і має визначатися зміст кінокартин. Кіно має у високих зразках мистецтва відобразити героїчну боротьбу за соціалізм і героїв цієї боротьби, історичний шлях пролетаріату, його партії $\mathrm{i}$ 
профспілок, життя і побут робітників, історію громадянської війни; воно має служити цілям мобілізації трудящих на зміцнення обороноздатності СРСР (Раззаков, 2008: 23).

Чергова спроба «вдосконалення» механізму управління радянським кінематографом датується 17 січня 1936 р., коли для об'єднання всього керівництва розвитком мистецтв в СРСР була ухвалена Постанова Центрального виконавчого комітету і Ради народних комісарів СРСР «Про утворення Всесоюзного комітету в справах мистецтв при РНК Союзу РСР». На новостворений комітет було покладено керівництво всіма справами мистецтв (Скрипник, 2016: 13).

Постанова РНК УРСР від 25 квітня 1937 р. «Про роботу Українфільму» засвідчила, що внаслідок недоліків у діяльності тресту, український кінематограф знаходиться у стані застою. Задля виправлення ситуації, РНК УРСР ставить перед керівництвом «Українфільму» вимогу зміцнити ідейнохудожній та оперативний провід кіностудіям, забезпечити виготовлення доброякісних сценаріїв та удосконалити всю постановку кіновиробництва (Самойленко, 2010: 35).

23 березня 1938 р. з'являється Постанова РНК СРСР «Про утворення Комітету в справах кінематографії при Раді народних комісарів Союзу РСР», що завершує процес повної централізації управління кінематографом (Скрипник, 2016: 13).

Відповідно до Постанови РНК УРСР від 16 квітня 1938 р. «Про утворення управління кінофікації при Раді народних комісарів УРСР, Раді народних комісарів Молдавської РСР і обласних виконавчих комітатах» трест «Українфільм» ліквідовувався, а всі страви, майно й цінності передавалися Управлінню кінофікації при РНК УРСР (Самойленко, 2010: 35).

Дещо пізніше, у 1940 р., особисто Йосипом Сталіним прийнято рішення про створення урядової комісії 3 обов'язкового попереднього перегляду кіноматеріалів, до складу якої ввійшли Андрій Жданов, Григорій Маленков та 
Андрій Вишинський, а також про заборону публікації рецензій на фільми, що не пройшли перевірки чи були відхилені комісією.

Проте паралельно з процесами «закручування гайок» у грудні того ж року ухвалювалося рішення про порядок присудження Сталінських премій у галузі літератури та мистецтва. В офіційній радянській ієрархії мистецтв кінематограф остаточно перетворюється на мистецтво номер один i контролюється тепер на ще вищому державному рівні.

А 14-15 травня 1941 р. в ЦК ВКП(б) відбувається розширена нарада представників радянської кінематографії, де із доповіддю виступив секретар ЦК А. Жданов. Основний акцент його виступу зводився до необхідності повороту в пропаганді задля виховання радянських людей у наступальному дусі. Ще не раз під час Другої світової радянська влада звернеться до кіно 3 метою підтримати бойовий дух солдат, заборонить показ тих фільмів, які не переживуть перевірку партійних критиків і робитиме все для поширення потрібної уряду СРСР «правди» у стрічках воєнних років (Скрипник, 2016: 298-299).

Від 22 червня 1941 р. і аж до 1944-го р. Україна перебуває під німецькою окупацією. На товариство «Українфільм», згідно з постановою керівництва німецької окупаційної влади, зокрема гауляйтера Еріка Коха від 8 грудня 1941 p., було покладено керівництво кінопроцесом у рейхскомісаріаті «Україна» (Удовик, 2004: 404-409).

Тим часом радянським урядом, зокрема Головним управлінням політичної пропаганди РСЧА 4 січня 1941 р. було видано директиву, у якій затверджувався перелік рекомендованих для перегляду в умовах воєнного часу художніх $\mathrm{i}$ документальних фільмів.

За часів «відлиги» під керівництвом i контролем ЦК КПРС безпосередньою працювало Міністерство культури СРСР і Держкіно СРСР. Керівництво кінематографією в СРСР здійснювалося через державні комітети союзних республік з кінематографії, які підпорядковувалися Раді Міністрів відповідних союзних республік і державному комітету СРСР з кінематографії; 
структура та чисельність союзних комітетів затверджувалася Радою Міністрів CPCP.

Самостійність республіканських комітетів була умовною. Загальне управління кінематографом здійснювала Рада Міністрів УРСР через Державний комітет Ради Міністрів УРСР 3 кінематографії та Спілку кінематографістів УРСР.

Згідно з постановою Ради Міністрів СРСР від 6 лютого 1958 р. була створена Спілка кінематографістів УРСР, яка і в подальшому відіграла важливу роль у розвитку українського кінематографа (Горячев, 1984: 110).

Державний Комітет Ради Міністрів СРСР з кінематографії було створено 23 березня 1963 р. як самостійний орган, який до цього часу входив до складу Міністерства культури. Відповідно, було створено й республіканські кінокомітети, які на місцях керували розвитком кіногалузі та здійснювали ідеологічний контроль за напрямком і змістом іiі розвитку. Кінокомітет неодноразово зазнавав змін структури та назви, при цьому його функції залишались незмінними. 9 грудня 1965 р. його було перетворено на Комітет по кінематографії при Раді міністрів СРСР. Таким чином, статус організації було знижено, адже голова комітету не входив до складу Ради Міністрів СРСР, як це було раніше.

Наступного датою реорганізації було 4 серпня 1972 р., коли Комітет по кінематографії при Раді міністрів СРСР перейменовано у союзнореспубліканський Державний комітет Ради Міністрів по кінематографії. Відповідно до цих змін, 28 серпня 1972 р. Президія Верховної Ради УРСР постановила перетворити Комітет при Раді Міністрів УРСР у союзнореспубліканський державний комітет Ради Міністрів УРСР по кінематографії (Держкіно УРСР). 14 червня 1974 р. було прийнято «Положення про Державний комітет Ради Міністрів Української РСР по кінематографії», яке визначало його завдання, функції та структуру. Так, Державний Комітет по кінематографії визначався як союзно-республіканський орган, який здійснював керівництво кінематографічною галуззю в країні, відповідав за іiі розвиток та 
ідейно-художній зміст кінопродукції. Одним 3 основних завдань було створення фільмів, які б сприяли формуванню у громадян відданості партійним ідеалам, радянському світогляду та патріотизму, протистояння буржуазним впливам капіталістичної кінопродукції. До повноважень Держкомітету входило визначення репертуарної політики, фінансове керівництво галуззю, піклування про впровадження останніх досягнень науки та техніки у кіновиробництво та населення.

Також основне завдання кіно у комуністичному вихованні сформульовано у низці партійних постанов: «Про заходи до дальшого розвитку радянської кінематографії» (1972 р.), «Про літературно-художню критику» (1972 р.), «Про дальше поліпшення ідеологічної, політико-виховної роботи» (1979р.) та ін.

На початку 1980-х pp. $з$ питань кіно було прийнято постанову «Про роботу Держкіно УРСР по виконанню рішень XXVI з'їзду КПРС, постанов ЦК КПРС і ЦК Компартії України з питань підвищення ідейно-художнього рівня фільмів і поліпшення кінообслуговування населення за 1982 р.». В ній підсумовувався ряд здійснених заходів, спрямованих на підвищення ідейно-художнього рівня фільмів.

У 1984 р. світ побачила постанова «Про заходи по дальшому підвищенню ідейно-художнього рівня кінофільмів і зміцнення матеріально-технічної бази кінематографії» (Ховайба, 2009: 96).

Відчуття нових змін і початок зрушень в радянському кінематографі прийшли лише після V з'їзду Союзу кінематографістів СРСР, що відбувся в травні 1986 р. На ньому вперше публічно було піддано критиці практику державного втручання у творчі процеси. А 5 серпня 1988 р. Верховна Рада УРСР ліквідувала Державний комітет по кінематографії, Україна фактично залишилася без державного органу, відповідального за розвиток кіно. Після здобуття незалежності, подібну структуру намагався відновити Юрій Іллєнко, створюючи у серпні 1991 р. Державний фонд української кінематографії, який проіснував до 13 травня 1993 р. 
Вже згодом, у 1998 р. тогочасним президентом Леонідом Кучмою, був підписаний підготовлений Верховною Радою Закон України «Про кінематографію». Протягом всієї історії незалежної України до Закону багаторазово вносились зміни та доповнення, останні з яких - у жовтні 2019 p.

Даний Закон визначає правові основи діяльності в галузі кінематографії та регулює суспільні відносини, пов'язані з виробництвом, розповсюдженням, зберіганням і демонструванням фільмів.

Основними принципами сучасної кінематографії закон називає:

- утвердження творами кінематографії ідей гуманізму, загальнолюдських, національно-культурних та духовних цінностей;

- сприяння розвиткові національної свідомості, патріотичних почуттів, естетичного та екологічного виховання громадян;

- гарантування свободи творчості, захисту інтелектуальної власності, авторських і суміжних прав, моральних і матеріальних інтересів суб'єктів кінематографії;

- розвиток кіноіндустрії та традицій національної кінематографії;

- збереження національної та світової кінематографічної спадщини;

- рівність прав і можливостей суб'єктів кінематографії незалежно від форм власності у виробництві, розповсюдженні та демонструванні (публічному показі) фільмів;

- заохочення благодійної діяльності;

- сприяння аматорській творчості в кінематографії;

сприяння співробітництву суб’єктів кінематографії 3 іноземними та міжнародними кінематографічними асоціаціями, фондами тощо (Про кінематографію, 2019).

У лютому того ж року вийшла Постанова Кабінету Міністрів України «Про стан та шляхи розвитку національної кінематографії», де зокрема зазначалось, що «...у період реформування суспільно-економічних відносин в Україні, єдина державна система кінематографії була зруйнована. При цьому паралельно не сформувалася ії концептуально нова модель, пристосована до 
ринкових умов». Документ закріпив десятикратне скорочення кількості фільмів та відвідувань кінотеатрів, засвідчив, що передання 1991 р. кіно-прокату i кіномережі до комунальної власності розірвало замкнений економічний цикл галузі, внаслідок чого наявний стан державної кіномережі не передбачає можливості повернути гроші витрачені на виробництво фільмів...

Виходячи з нагальної необхідності реформування галузі, Постановою було зазначено: «На сьогодні найбільш прийнятним $є$ послідовний перехід до ринкової системи господарювання в кінематографії, яка має поєднувати державну підтримку з інвестиціями підприємців. В результаті мають бути сформовані сучасна національна кіноіндустрія і національний кіноринок». У загальних рисах документ сформулював завдання на наступне десятиліття перше десятиліття XXI ст. (Зубавіна, 2007: 104).

На сьогодні одну з найголовніших ролей в кіноіндустрії нашої країни відіграє Державне агентство України з питань кіно, яке було засноване у 2006 р. Держкіно України входить до системи органів виконавчої влади та забезпечує реалізацію державної політики у сфері кінематографії. На сьогоднішній день агенство очолює Юлія Шевчук (Постанова КМУ, 2014).

У 2018 р. була створена Рада 3 державної підтримки кінематографії, діяльність якої має на меті створення сприятливих умов для розвитку кіновиробництва, встановлення прозорих процедур здійснення фінансування державою проектів у сфері кінематографії (Про державну підтримку, 2019).

Президент України Володимир Зеленський підписав Закон «Про внесення змін до Закону «Про державну підтримку кінематографії в Україні», якими передбачено надання державної субсидії для повернення частини кваліфікованих витрат, здійснених іноземним суб'єктом кінематографії при виробництві фільму в Україні» №130-ІХ, який Верховна Рада ухвалила 20 вересня 2019 р. (Зеленський підписав закон, 2019).

Висновки. В цілому від появи кінематографа і до його демонстрування на наших екранах сьогодні, було створено чимало керівних державних структур, метою діяльності яких було підпорядкування кіноіндустрії як важливого 
чинника впливу на свідомість людей. У радянській період такими були Всеукраїнське фотокіноуправління, Управління в справах Кінематографії, Міністерство Кінематографії Української РСР, Головне управління 3 виробництва фільмів, Державний комітет по кінематографії УРСР. 3 прийняттям незалежності - Державний фонд української кінематографії, Державна служба кінематографії i нарешті Державне агентство України 3 питань кіно. Так в загальному суспільному контексті розвитку української нації, українське кіно пройшло свій шлях розвитку, зокрема і в нормативноправовому полі. Минули часи і кіно вже не підпорядковується ідеологічним засадам, закріпленим на державному рівні. Після важкого становища на початку 2000-х років українське кіно змогло стати на ноги. Популяризувати не партію, а націю, от що нині в пріоритеті державної політики у галузі кінематографа, про це зокрема i свідчать останні законодавчі зміни від президента В. Зеленського.

\section{СПИСОК ВИКОРИСТАНИХ ДЖЕРЕЛ І ЛІТЕРАТУРИ}

Гак, 1973 - Самое важное из всех искусств. Ленин о кино / Сост. Гак А. М. Изд. 2-е, дополненное. Москва : Искусство, 1973. $224 \mathrm{c}$.

Горячев, 1984. - Горячев Ю. И. Шинкаренко Ю. И. Источник силы. О партийном руководстве развитием советской кинематографии. Москва : Искусство, 1984. С. 189.

Евтушенко, 2013 - Евтушенко А. М. Ленинский декрет от 27 августа 1919 года в контексте истории отечественного кино. // Весник Воронежского государственного университета. Воронеж : Воронежский государственный университет. (Филология. Журналистика. № 2). 2013. С. 130-133.

Зеленський підписав закон, 2019 - Зеленський підписав скандальний закон про підтримку іноземних виробників в Україні. Прямий. 2019. URL: https://prm.ua/zelenskiy-pidpisav-skandalniy-zakon-pro-pidtrimku-inozemnihkinovirobnikiv-v-ukrayini/.

Зубавіна, 2007 - Зубавіна І. Кінематограф незалежної України: тенденції, фільми, постаті. Київ : Інститут проблем сучасного мистецтва, 2007. 296 с.

Миславський, 2018 - Миславський В. Н. Історія українського кіно 1896-1930: факти і документи. Т. 1. Харків : «Дім Реклами», 2018. $680 \mathrm{c}$.

Постанова КМУ, 2014. Постанова Кабінету Міністрів України. Положення про Державне агентство України з питань кіно від 17.07.2014. № 277. Дата оновлення: № 885 від 16.10.2019. URL: https://zakon.rada.gov.ua/laws/show/277-2014$\% \mathrm{D} 0 \% \mathrm{BF}$

Про кінематографію, 2019 - Про кінематографію: Закон України: від 13.01.1998 № 9/98-ВР. Дата оновлення №164-IX від 03.10.2019. URL: https://zakon.rada.gov.ua/laws/show/9/98-\%D0\%B2\%D1\%80/print.

Про державну підтримку, 2019. Про державну підтримку кінематографії в Україні Закон України від 23.03.2017. № 1977-VIII. Дата оновлення: № 164-IX від 03.10.2019 [URL] - URL: https://zakon.rada.gov.ua/laws/show/1977-19.

Раззаков, 2008. Раззаков Ф. Гибель советского кино. Интриги и споры. 1918-1972. Москва : Эксмо, 2008.189 с.

Росляк, 2014 (а) - Росляк Р. «Віддати наказ про припинення самостійного існування ВУФКУ...» (матеріали й документи з історії підпорядкування української кінематографії союзному центру) // Студії мистецтвознавчі. Київ, 2014. Число 3. С. 112-126.

Росляк, 2014 (b) - Росляк Р. Вітчизняне кіномистецтво і процеси українізації: 20-і - початок 30-х років ХХ століття // Вісник Національної академії керівних кадрів культури і мистецтв. Київ, 2014. №1. С. 215-220.

Росляк, 2014 (с) - Росляк Р. Націоналізація кінематографа в Україні // Вісник національної академії керівних кадрів культури і мистецтвв. Київ, 2011. №3. С. 171-175. 
Самойленко, 2016 - Самойленко Т. І. Українське кіно в умовах тоталітарного режиму // Наукові праці Чорноморського державного університету імені Петра Могили. Серія: історія. Миколаїв, 2010. Т. 129. Вип. 116. C. 32-36.

Скрипник та ін., 2016 - Історія українського кіно. Т. 2 : 1930-1945 / Г. Скрипник та ін. Київ : НАН України; ІМФЕ ім. М. Т. Рильського, 2016. 448 с.

Тримбач, 2016 - Тримбач С. Кіно народжене Україною. Київ : Техніка, 2016. 384 с.

Удовик, 2004 - Удовик В. Київська кіностудія в період німецької окупації (1941-1943) // 3 архівів ВУЧК-ГПУ-НКВДКГБ № 1/2 (22/23). Київ, 2004. С. $404-409$.

Ховайба, 2009. Ховайба Н. Ідеологічна складова українського радянського кінематографа середини 1960-х-середини 1980-х років // Етнічна історія народів Свропи. Київ, 2009. №29. С. 95-99.

\section{REFERENCES}

Hak, 1973 - Samoe vazhnoe yz vsekh yskusstv. Lenyn o kyno [The most important of all the arts. Lenin about the movie] / Sost. Hak A. M. Yzd. 2-e, dopolnennoe. Moskva : Yskusstvo, 1973. 224 s. [in Russian]

Horiachev, 1984. - Horiachev Yu. Y. Shynkarenko Yu. Y. Ystochnyk syly. O partyinom rukovodstve razvytyem sovetskoi kynematohrafyy [Source of power. On the party leadership in the development of Soviet cinematography]. Moskva : Yskusstvo, 1984. S. 189 [in Russian]

Evtushenko, 2013 - Evtushenko A. M. Lenynskyi dekret ot 27 avhusta 1919 hoda v kontekste ystoryy otechestvennoho kyno [Lenin's decree of August 27, 1919 in the context of the history of Russian cinema]. Vesnyk Voronezhskoho hosudarstvennoho unyversyteta. Voronezh : Voronezhskyi hosudarstvennыi unyversytet. (Fylolohyia. Zhurnalystyka. № 2). 2013. S. 130-133 [in Russian]

Zelenskyi pidpysav zakon, 2019 - Zelenskyi pidpysav skandalnyi zakon pro pidtrymku inozemnykh vyrobnykiv v Ukraini. Priamyi. 2019. URL: https://prm.ua/zelenskiy-pidpisav-skandalniy-zakon-pro-pidtrimku-inozemnihkinovirobnikiv-v-ukrayini/ [in Ukrainian]

Zubavina, 2007 - Zubavina I. Kinematohraf nezalezhnoi Ukrainy: tendentsii, filmy, postati [Cinema of independent Ukraine: trends, films, figures]. Kyiv : Instytut problem suchasnoho mystetstva, 2007. 296 s. [in Ukrainian]

Myslavskyi, 2018 - Myslavskyi V. N. Istoriia ukrainskoho kino 1896-1930: fakty i dokumenty [History of Ukrainian cinema 1896-1930: facts and documents]. T. 1. Kharkiv : «Dim Reklamy», 2018. 680 s. [in Ukrainian]

Postanova KMU, 2014. Postanova Kabinetu Ministriv Ukrainy. Polozhennia pro Derzhavne ahentstvo Ukrainy z pytan kino vid 17.07.2014. № 277. Data onovlennia: № 885 vid 16.10.2019. URL: https://zakon.rada.gov.ua/laws/show/277_2014-\%D0\%BF [in Ukrainian]

Pro kinematohrafiiu, 2019 - Pro kinematohrafiiu: Zakon Ukrainy: vid 13.01.1998 № 9/98-VR. Data onovlennia №164IX vid 03.10.2019. URL: https://zakon.rada.gov.ua/laws/show/9/98-\%D0\%B2\%D1\%80/print [in Ukrainian]

Pro derzhavnu pidtrymku, 2019. Pro derzhavnu pidtrymku kinematohrafii v Ukraini Zakon Ukrainy vid 23.03.2017. № 1977-VIII. Data onovlennia: № 164-IX vid 03.10.2019 [URL] - URL: https://zakon.rada.gov.ua/laws/show/1977-19 [in Ukrainian]

Razzakov, 2008. Razzakov F. Hybel sovetskoho kyno. Yntryhy y spory [The death of Soviet cinema. Intrigues and disputes. 1918-1972]. 1918-1972. Moskva : Эksmo, 2008. 189 s. [in Russian]

Rosliak, 2014 (a) - Rosliak R. «Viddaty nakaz pro prypynennia samostiinoho isnuvannia VUFKU...» (materialy y dokumenty $\mathrm{z}$ istorii pidporiadkuvannia ukrainskoi kinematohrafii soiuznomu tsentru) [«Give an order to terminate the independent existence of VUFKU" (materials and documents on the history of subordination of Ukrainian cinematography to the Union Center)]. Studii mystetstvoznavchi. Kyiv, 2014. Chyslo 3. S. 112-126 [in Ukrainian]

Rosliak, 2014 (b) - Rosliak R. Vitchyzniane kinomystetstvo i protsesy ukrainizatsii: 20- kh - pochatok 30-kh rokiv XX stolittia [Soviet cinema and Ukrainization processes: 20s-early 30s of the twentieth century]. Visnyk Natsionalnoi akademii kerivnykh kadriv kultury i mystetstv. Kyiv, 2014. №1. S. 215-220 [in Ukrainian]

Rosliak, 2014 (s) - Rosliak R. Natsionalizatsiia kinematohrafa v Ukraini [Nationalization of cinema in Ukraine]. Visnyk natsionalnoi akademii kerivnykh kadriv kultury i mystetstv. Kyiv, 2011. №3. S. 171-175 [in Ukrainian]

Samoilenko, 2016 - Samoilenko T. I. Ukrainske kino v umovakh totalitarnoho rezhymu [Ukrainian cinema under a totalitarian regime]. Naukovi pratsi Chornomorskoho derzhavnoho universytetu imeni Petra Mohyly. Seriia: istoriia. Mykolaiv, 2010. T. 129. Vyp. 116. S. 32-36 [in Ukrainian]

Skrypnyk ta in., 2016 - Istoriia ukrainskoho kino [History of Ukrainian cinema]. T. 2 : 1930-1945 / H. Skrypnyk ta in. Kyiv : NAN Ukrainy; IMFE im. M. T. Rylskoho, 2016. 448 s. [in Ukrainian]

Trymbach, 2016 - Trymbach S. Kino narodzhene Ukrainoiu [Cinema born in Ukraine]. Kyiv : Tekhnika, 2016.384 s. [in Ukrainian]

Udovyk, 2004 - Udovyk V. Kyivska kinostudiia v period nimetskoi okupatsii (1941-1943) [Kiev film studio during the German occupation (1941-1943)]. Z arkhiviv VUChK-HPU-NKVD-KHB № 1/2 (22/23). Kyiv, 2004. S. 404-409 [in Ukrainian]

Khovaiba, 2009. Khovaiba N. Ideolohichna skladova ukrainskoho radianskoho kinematohrafa seredyny 1960-khseredyny 1980-kh rokiv [Ideological component of Ukrainian Soviet cinema in the mid-1960s-mid-1980s.]. Etnichna istoriia narodiv Yevropy. Kyiv, 2009. №29. S. 95-99 [in Ukrainian] 